\title{
Clinical Application of Virtual Reality for Upper Limb Motor Rehabilitation in Stroke: Review of Technologies and Clinical Evidence
}

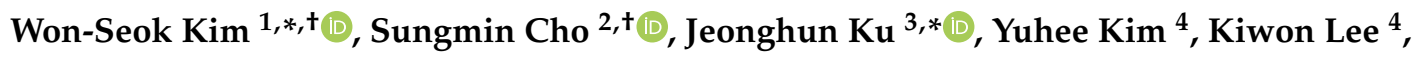 \\ Han-Jeong Hwang ${ }^{5}\left(\mathbb{D}\right.$ and Nam-Jong Paik ${ }^{1}$ (1) \\ 1 Department of Rehabilitation Medicine, Seoul National University College of Medicine, Seoul National \\ University Bundang Hospital, Seongnam-si, Gyeonggi-do 13620, Korea; njpaik@snu.ac.kr \\ 2 Delvine Inc., Seoul 08788, Korea; cho@delvine.co.kr \\ 3 Department of Biomedical Engineering, College of Medicine, Keimyung University, Daegu 42601, Korea \\ 4 Ybrain Research Institute, Seongnam-si, Gyeonggi-do 13449, Korea; yuhee.kim@ybrain.com (Y.K.); \\ kiwon.lee@ybrain.com (K.L.) \\ 5 Department of Electronics and Information, Korea University, Sejong 30019, Korea; hwanghj@korea.ac.kr \\ * Correspondence: wondol77@gmail.com (W.-S.K.); kujh@kmu.ac.kr (J.K.); \\ Tel.: +82-31-787-7735 (W.-S.K.); +82-53-258-7535 (J.K.) \\ + These authors contributed equally to this work.
}

Received: 22 September 2020; Accepted: 19 October 2020; Published: 21 October 2020

check for updates

\begin{abstract}
Neurorehabilitation for stroke is important for upper limb motor recovery. Conventional rehabilitation such as occupational therapy has been used, but novel technologies are expected to open new opportunities for better recovery. Virtual reality (VR) is a technology with a set of informatics that provides interactive environments to patients. VR can enhance neuroplasticity and recovery after a stroke by providing more intensive, repetitive, and engaging training due to several advantages, including: (1) tasks with various difficulty levels for rehabilitation, (2) augmented real-time feedback, (3) more immersive and engaging experiences, (4) more standardized rehabilitation, and (5) safe simulation of real-world activities of daily living. In this comprehensive narrative review of the application of VR in motor rehabilitation after stroke, mainly for the upper limbs, we cover: (1) the technologies used in VR rehabilitation, including sensors; (2) the clinical application of and evidence for VR in stroke rehabilitation; and (3) considerations for VR application in stroke rehabilitation. Meta-analyses for upper limb VR rehabilitation after stroke were identified by an online search of Ovid-MEDLINE, Ovid-EMBASE, the Cochrane Library, and KoreaMed. We expect that this review will provide insights into successful clinical applications or trials of VR for motor rehabilitation after stroke.
\end{abstract}

Keywords: virtual reality; stroke; rehabilitation; hemiplegia; recovery of function; neuronal plasticity; sensor

\section{Introduction}

Stroke is one of the leading causes of disability and socioeconomic burden worldwide [1]. Although the age-standardized stroke incidence has decreased in most regions, the growth of aging populations, who are at risk of stroke, may lead to an increase in the crude incidence of stroke [2]. According to a policy statement by an American Heart Association working group, approximately $4 \%$ of US adults will have a stroke by 2030 [3]. Stroke-related mortality has shown a remarkable decline due to better management in the acute phase, which means there are more people living with disabilities after stroke $[1,3]$. 
Upper limb hemiparesis is one of the most common impairments after stroke [4] and is associated with activity limitation and a worse quality of life [5-7]. Therefore, adequate recovery of upper limb weakness is necessary. Spontaneous motor recovery occurring up to one year after stroke can be accelerated with active rehabilitation strategies $[8,9]$. However, the effects of conventional rehabilitation modalities are limited and novel therapeutic approaches are required [10].

Virtual rehabilitation using virtual reality (VR) technology is a novel promising modality for motor rehabilitation after stroke [11] that can add beneficial components to current rehabilitation strategies. Considering motor learning theory, task-oriented, intensive (that is, more doses and movements), and repetitive training is essential for promoting neuroplasticity and thereby, motor recovery (Figure 1) [12]. Several advantages of virtual rehabilitation can be suggested in terms of rehabilitation intensity and motivation. VR can motivate patients' participation by increasing enjoyment and gamification- 'the process of adding game-design elements and game principles to something (e.g., task) so as to encourage participation"- thereby increasing task repetition (intensity) [13-15]. Flexible and individualized rehabilitation design is possible according to the patient's motor impairment, which makes the step-by-step approach possible. A low-cost virtual rehabilitation system can be used as an adjunctive therapy to conventional rehabilitation, with less direct supervision by a therapist [16], and it can also be considered for use as a tele- or home-based rehabilitation tool [17]. Functional assessment and digital tracking of patients' progress is possible using motion sensors combined with VR systems for rehabilitation [18].

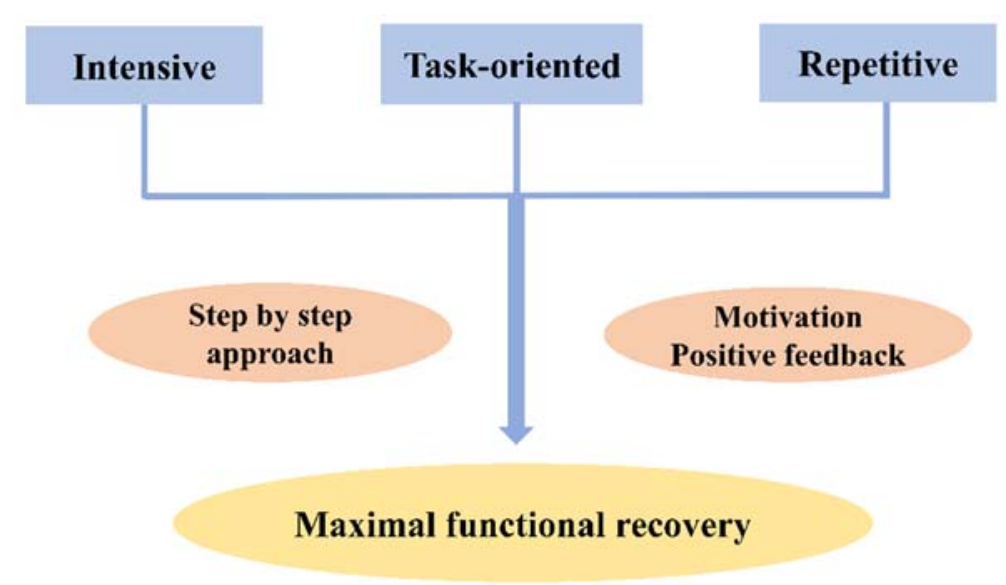

Figure 1. Approaches to promote neural plasticity.

In this comprehensive narrative review of the application of VR in motor rehabilitation after stroke, we will cover (1) the technologies used in VR rehabilitation including sensors, haptic devices, and VR displays; (2) the clinical application and evidence for VR in motor rehabilitation in stroke; and (3) considerations for VR application in stroke rehabilitation. We expect that this review will provide insights into successful clinical applications or trials of VR for motor rehabilitation after stroke.

\section{Technologies Used in VR Rehabilitation}

\subsection{Definition of $V R$}

VR technology can give users the experience of being surrounded by a computer-generated world. With VR, users experience inclusive and extensive surroundings, with vivid illusions of a virtual computer generated environment in which both realistic and unrealistic events can occur. So, users can interact as though they are in a real environment and may not even recognize that they are existing in a virtual environment [19]. Therefore, in VR, participants can be fully immersed in the surrounding virtual environment and interact naturally with virtual objects in the virtual world [20]. Because VR content responds to a user's movements in a natural and valid manner, such as showing 
the corresponding scene on the display when the user looks at it, the interaction evokes a feeling of existing in a virtual environment, which is referred to as "presence." Moreover, control of the avatar's body movements by those of the user can even induce a feeling of ownership in which the user regards the avatar's body parts as surrogates of their own, a phenomenon called "virtual embodiment" [21]. Based on these factors, users are fully immersed, which allows them to experience where they are and what they do there in a way that is similar to real/lived experience.

\subsection{Non-Immersive and Immersive VR}

Non-immersive VR allows users to experience a virtual environment as observers and interact with the virtual environment by using devices that cannot fully overwhelm sensory perceptions [22], which results in a lesser feeling of immersion in the virtual world. Non-immersive VR systems are mainly characterized by users' ability to control their surroundings while perceiving stimuli around them, such as sounds, visuals, and haptics. Non-immersive VR systems are primarily based on a computer or video game console, flat screen, or monitor and input devices such as keyboards, mice, and controllers. Non-immersive VR systems can also use other physical input devices, such as racing wheels, pedals, and speed shifters, to augment users' realistic experiences. Using various input devices, users can interact with VR content on a display. To enhance the level of immersion, some non-immersive VR systems provide a first-person view for users to associate themselves with their virtual avatar. To allow users to perceive objects as being 3D, stereoscopic vision technology, with which stereo images are provided so that each eye of the user, who wears special goggles, receives the same scene but from a slightly different angle, could be used, which would allow the user to feel the third dimension from a 2D monitor or screen [23].

Immersive VR, on the other hand, improves the feeling of presence, enabling people to feel more like they are actually in the virtual environment, which means that users are more likely to interact with the stimuli given by the computer and related devices providing visual, auditory, and haptic sensations. The main goal of immersive VR is to make it possible for users to experience the illusion of being in the computer-generated environment rather than the real-world environment. By wearing a head-mounted display (HMD), tracking devices, haptic devices, and data gloves and by using wireless controllers, users can be placed in virtual environments and interact with a computer-generated world. However, the real world has a greater variety of senses including smell, taste, the feeling of warm and cold, etc., which may increase the gap between the virtual and real worlds. These could be further covered by complete immersive VR, but the need for a sophisticated artificial stimulator to provide variable sensations may require more space and have a higher cost. HMD-based immersive VR could also be enriched using physical objects or devices placed in the physical space by tracking their positions precisely in relation to where the user stands. By using this paradigm, the user could perceive the texture or temperature of objects without any awkwardness when touching it because the physical object is tracked to be placed at the same position as that in the virtual space; thus, the user touches the physical object when they touch the virtual object. Another issue to overcome is that the user must be placed in a limited space; therefore, their walking area is constrained. Using a VR treadmill allows users to physically walk or run toward any place in a virtual environment by solving two problems: realistic synchronized simulation of the user's walk and no requirement for a large space. The Cave Automatic Virtual Environment (CAVE) has been introduced as another way to provide visual information for immersive VR, instead of using an HMD [24]. CAVE uses six large walls on which scenes are displayed so that the participant can be placed in the CAVE and experience the surrounding virtual environment with a large field of view.

Immersive and non-immersive environments can be better differentiated by their level of immersion. Immersive VR strengthens the level of immersion because less mental effort is required to be immersed in the virtual environment since the hardware systems cover most sensory perceptions. In contrast, non-immersive VR requires more mental effort to be immersed in the virtual environment. 
Therefore, non-immersive VR may reduce the level of spatial presence, which is defined as "the sense of being in an environment" $[25,26]$.

\subsection{Technologies for Motion Tracking and Feedback for Virtual Rehabilitation}

Virtual rehabilitation is a method of rehabilitation via gamification through synchronization with software content or by providing a motion guide. Various studies have been conducted to investigate the application of VR for upper limb rehabilitation (Table 1).

For motor rehabilitation of limbs, the patient's body part must be captured by motion tracking sensors and synchronously transferred to an object in VR. Sensors to track the patient's motion are mandatory for movement visualization and can be selected from a mouse and joystick, depth-sensing cameras, electromagnetic sensors, inertial sensors, bending sensors, data gloves, and so on. The sensor performance is important to precisely track the motion, but the subjective perception and preferences are also important factors to be considered, in addition to cost [27].

A sensor technology that recognizes motion is essential for virtual rehabilitation. Such technologies are divided into wearable and nonwearable devices that recognize upper limb rehabilitation motions. Nonwearable devices are further divided into those using a vision sensor and those using a robot-based controller or a controller with three degrees of freedom (DOF) either alone or in combination. Wearable devices are usually divided into those using data gloves and those using an exoskeleton. Some studies have used both types together. Sensing using cameras in nonwearable devices has recently changed from tracking markers or color patches using webcams to tracking body or hand signals through depth sensing methods. In this way, the users' movements are sensed within a limited space without obstacles. With wearable devices, the sensor is attached to collect high frequency data and force or torque can be tracked as well as position and movement.

Most studies have primarily used visual and auditory feedback through content and some studies have applied tactile and force feedback (which are haptic feedback). We divided the studies into visuomotor and visuohaptic feedback. Visuomotor feedback provides visual information by applying measured movements through sensors to content in real time. Visuohaptic feedback refers to providing haptic feedback with visual information. Haptic feedback could be divided into tactile or force feedback, depending on whether resistance is present. Tactile feedback provides feedback to users through the sense of touch using vibration, skin deformation, or small forces. Force feedback, or kinesthetic force feedback, simulates real-world physical touch using motorized motion or resistance rather than by fine touch [28]. Research on virtual rehabilitation can be categorized according to the use of fine motor tracking during upper limb rehabilitation, which is distinguished by the use of wearable or nonwearable devices. In the case of camera methods among nonwearable devices, hand tracking is possible with a HMD for VR, and this has been released as a commercial product (e.g., Oculus Quest, Facebook Technologies, LLC, Menlo Park, CA, USA). The sensor types used in previous studies are summarized in Figure 2. 
Table 1. Virtual rehabilitation studies for upper limb rehabilitation.

\begin{tabular}{|c|c|c|c|c|c|}
\hline Study & Sensor Type & $\begin{array}{l}\text { Sensor Type } \\
\text { (Detail) }\end{array}$ & Feedback Type & VR Type & $\begin{array}{l}\text { Rehabilitation } \\
\text { Part }\end{array}$ \\
\hline \multicolumn{6}{|c|}{ Visuomotor Feedback } \\
\hline $\begin{array}{c}\text { Dimbwadyo-Terrer et al., } \\
2016[29]\end{array}$ & Wearable & Data glove & $\mathrm{V}$ & NI & $\begin{array}{l}\text { Arm, hand, } \\
\text { finger }\end{array}$ \\
\hline Crosbie et al., 2012 [30] & Wearable & Data glove, motion tracking sensor & $\mathrm{V}, \mathrm{A}$ & I & $\begin{array}{l}\text { Arm, hand, } \\
\text { finger }\end{array}$ \\
\hline Calabrò et al., 2019 [31] & Wearable & End-effector hand exoskeleton & $\mathrm{V}, \mathrm{A}$ & NI & Finger \\
\hline Kiper et al., 2018 [32] & Wearable & Electromagnetic sensor & $\mathrm{V}$ & NI & Arm, hand \\
\hline Cho et al., 2016 [33] & Nonwearable & $\begin{array}{l}\text { Motion-sensing camera (depth } \\
\text { sensing, hand tracking) }\end{array}$ & $\mathrm{V}, \mathrm{A}$ & NI & $\begin{array}{l}\text { Arm, hand, } \\
\text { finger }\end{array}$ \\
\hline Askin et al., 2018 [34] & Nonwearable & $\begin{array}{l}\text { Motion-sensing Camera (body } \\
\text { tracking with depth sensing) }\end{array}$ & $\mathrm{V}$ & NI & Arm \\
\hline Faria et al., 2018 [35] & Nonwearable & Marker-based tracking with webcam & $\mathrm{V}$ & NI & Arm, hand \\
\hline Lee et al., 2018 [36] & Nonwearable & $\begin{array}{l}\text { Controller for paddling movement } \\
\text { (canoe-like apparatus) }\end{array}$ & $\mathrm{V}, \mathrm{A}$ & NI & Arm, hand \\
\hline Sucar et al., 2014 [37] & Nonwearable & $\begin{array}{l}\text { Pressure sensor in custom gripper, } \\
\text { colored object tracking with webcam }\end{array}$ & $\mathrm{V}, \mathrm{A}$ & NI & Arm, hand \\
\hline Ballester et al., 2017 [38] & $\begin{array}{c}\text { Wearable, } \\
\text { nonwearable }\end{array}$ & $\begin{array}{l}\text { Motion-sensing camera (depth } \\
\text { sensing, body tracking), data glove }\end{array}$ & $\mathrm{V}$ & NI & $\begin{array}{l}\text { Arm, hand, } \\
\text { finger }\end{array}$ \\
\hline Sampson et al., 2012 [39] & $\begin{array}{c}\text { Wearable, } \\
\text { nonwearable }\end{array}$ & Colored object tracking with webcam & $\mathrm{V}$ & NI & Arm \\
\hline Xin et al., 2014 [40] & $\begin{array}{c}\text { Wearable, } \\
\text { nonwearable }\end{array}$ & $\begin{array}{l}\text { Motion-sensing camera (body } \\
\text { tracking with depth sensing), } \\
\text { EMG sensing }\end{array}$ & $\mathrm{V}$ & $\mathrm{I}$ & Arm \\
\hline \multicolumn{6}{|c|}{ Visuohaptic Feedback } \\
\hline Feintuch et al., 2006 [41] & Wearable & Colored glove tracking with webcam & $\mathrm{T}, \mathrm{V}, \mathrm{A}$ & NI & Arm \\
\hline Popescu et al., 2000 [42] & Wearable & Non-contact position sensors & $\mathrm{F}, \mathrm{V}, \mathrm{A}$ & NI & Hand, finger \\
\hline Prisco et al., 1998 [43] & Wearable & $\begin{array}{l}\text { Glove with electromagnetic } \\
\text { measurements, torque/force and joint } \\
\text { rotation sensing in arm exoskeleton }\end{array}$ & $\mathrm{F}, \mathrm{V}, \mathrm{A}$ & I & $\begin{array}{l}\text { Arm, hand, } \\
\text { finger }\end{array}$ \\
\hline $\begin{array}{l}\text { Alamri et al., } 2008 \text { [44], } \\
\text { Kayyali et al., } 2007 \text { [45] }\end{array}$ & Wearable & Data glove with hand exoskeleton & $\mathrm{F}, \mathrm{V}$ & NI & $\begin{array}{l}\text { Arm, hand, } \\
\text { finger }\end{array}$ \\
\hline Adamovich et al., 2009 [46] & Wearable & Data glove with hand exoskeleton & $\mathrm{F}, \mathrm{V}, \mathrm{A}$ & NI & $\begin{array}{l}\text { Arm, hand, } \\
\text { finger }\end{array}$ \\
\hline Molier et al., 2011 [47] & Wearable & $\begin{array}{l}\text { Potentiometer and optical encoder in } \\
\text { arm exoskeleton }\end{array}$ & $\mathrm{F}, \mathrm{V}, \mathrm{A}$ & NI & Arm, hand \\
\hline $\begin{array}{l}\text { Jack et al., } 2001 \text { [48] } \\
\text { Merians et al., } 2002[13]\end{array}$ & Wearable & $\begin{array}{l}\text { Non-contact position sensor, } \\
\text { data glove }\end{array}$ & $\mathrm{F}, \mathrm{V}, \mathrm{A}$ & NI & Hand, finger \\
\hline Wille et al., 2009 [49] & Wearable & $\begin{array}{c}\text { Data glove, accelerometers, and } \\
\text { magnetometers }\end{array}$ & $\mathrm{T}, \mathrm{V}$ & NI & $\begin{array}{l}\text { Arm, hand, } \\
\text { finger }\end{array}$ \\
\hline Connelly et al., 2009 [50] & Wearable & $\begin{array}{l}\text { Data glove, magnetic tracker for head } \\
\text { tracking }\end{array}$ & $\mathrm{T}, \mathrm{V}, \mathrm{A}$ & I & Hand, finger \\
\hline Huang et al., 2017 [51] & Wearable & $\begin{array}{l}\text { Position and force sensor in hand } \\
\text { rehabilitation robot }\end{array}$ & $\mathrm{V}, \mathrm{A}$ & I & Finger \\
\hline Pignolo et al., 2012 [52] & Wearable & Optical encoder in arm exoskeleton & $\mathrm{V}, \mathrm{A}$ & I & Arm \\
\hline $\begin{array}{l}\text { Andaluz et al., } 2016 \text { [53], } \\
\text { Bardorfer et al., } 2001 \text { [54] }\end{array}$ & Nonwearable & 3D controller including buttons & $\mathrm{F}, \mathrm{V}$ & NI & $\begin{array}{l}\text { Arm, hand, } \\
\text { finger }\end{array}$ \\
\hline Broeren et al., 2004 [55] & Nonwearable & 3D controller & $\mathrm{F}, \mathrm{V}$ & SI & Hand, finger \\
\hline Adamovich et al., 2009 [56] & Nonwearable & $\begin{array}{c}\text { Force sensor in } 3 \mathrm{DOF} \\
\text { admittance-controlled robot }\end{array}$ & $\mathrm{F}, \mathrm{V}$ & NI & Arm, hand \\
\hline Merians et al., 2011 [57] & Nonwearable & $\begin{array}{l}\text { Data glove, optical fiber curvature } \\
\text { sensor, force sensor in } 3 \text { DOF } \\
\text { admittance-controlled robot }\end{array}$ & $\mathrm{F}, \mathrm{V}$ & NI & $\begin{array}{l}\text { Arm, hand, } \\
\text { finger }\end{array}$ \\
\hline $\begin{array}{l}\text { Nagaraj e al., } 2009 \text { [58], } \\
\text { Chiang et al., } 2017 \text { [59] }\end{array}$ & Nonwearable & 3D controller & $\mathrm{F}, \mathrm{V}, \mathrm{A}$ & NI & Arm, hand \\
\hline Sadihov et al., 2013 [60] & $\begin{array}{l}\text { Wearable and } \\
\text { nonwearable }\end{array}$ & $\begin{array}{l}\text { Motion sensing camera (depth } \\
\text { sensing, body tracking), data glove } \\
\text { (bend sensing) }\end{array}$ & $\mathrm{T}, \mathrm{V}$ & NI & $\begin{array}{l}\text { Arm, hand, } \\
\text { finger }\end{array}$ \\
\hline Kapur et al., 2009 [61] & $\begin{array}{l}\text { Wearable and } \\
\text { nonwearable }\end{array}$ & Sleeve for optical tracking (camera) & $\mathrm{T}, \mathrm{V}$ & NI & Arm \\
\hline $\begin{array}{c}\text { Ramírez-Fernández et al., } \\
\text { 2015 [62] }\end{array}$ & $\begin{array}{l}\text { Wearable and } \\
\text { nonwearable }\end{array}$ & $\begin{array}{l}\text { 3D controller, motion sensing camera } \\
\text { (depth sensing, hand tracking) }\end{array}$ & $\mathrm{F}, \mathrm{V}, \mathrm{A}$ & NI & Arm, hand \\
\hline
\end{tabular}

In studies using only visual feedback, auditory feedback could possibly be used. Abbreviations: I, immersive; NI, non-immersive; SI, semi-immersive; T, tactile; F, force; V, visual; A, auditory; EMG, electromyography; DOF, degrees of freedom; VR: virtual reality. 


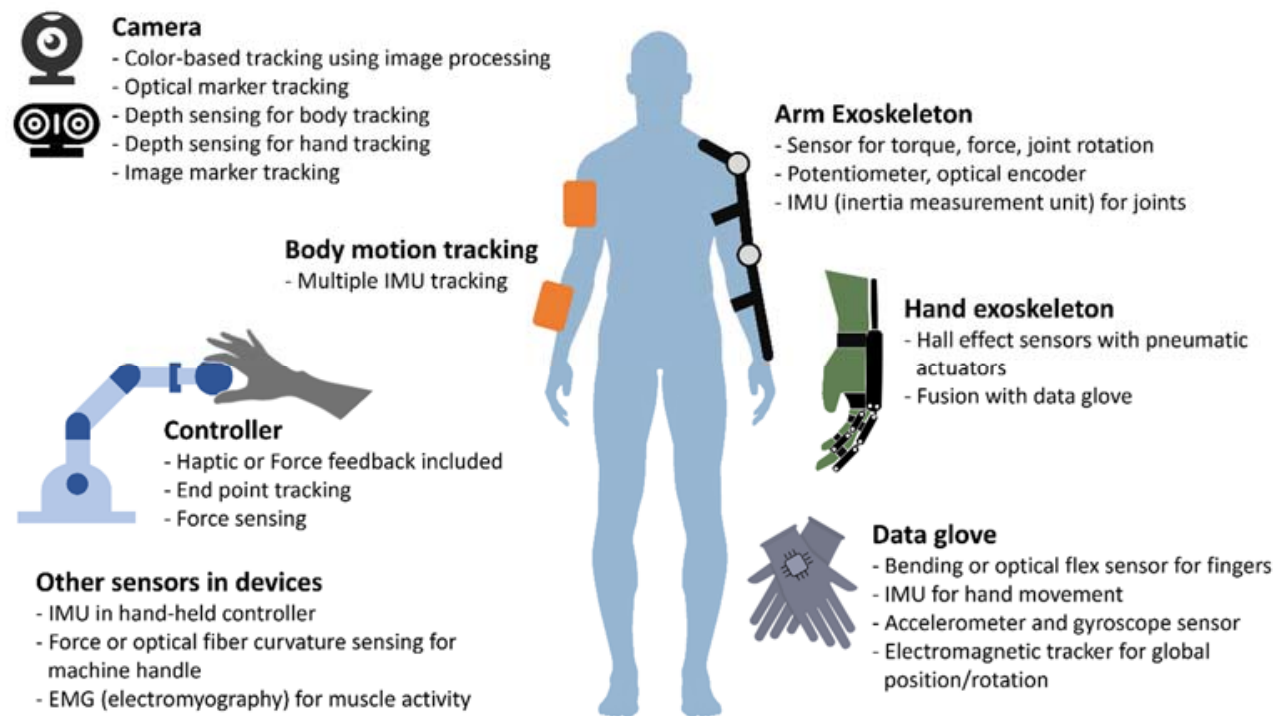

Figure 2. Classification of sensor types used in virtual rehabilitation for upper limb rehabilitation.

\subsection{Examples of Commercialized VR Upper Limb Rehabilitation Systems}

Commercialized virtual rehabilitation devices that can provide gamification through content or rehabilitation guides are similar to those used in VR rehabilitation research, but they are simplified and more focused on ease of use. Sensing methods are divided into wearable and nonwearable methods using cameras, joysticks, and robots (Table 2).

Table 2. Commercialized VR systems custom-built for upper limb rehabilitation.

\begin{tabular}{|c|c|c|c|c|c|}
\hline VR System & VR Type & Sensor Type & Body Part & Company & Country \\
\hline $\begin{array}{l}\text { Riablo } \\
\text { Premium }\end{array}$ & NI & IMU sensor & Arm & CoRehab & Italy \\
\hline SaeboVR & NI & $\begin{array}{l}\text { Motion-sensing camera (depth } \\
\text { sensing, body tracking) }\end{array}$ & Arm & Saebo & USA \\
\hline Doctor Kinetic & NI & $\begin{array}{l}\text { Motion-sensing camera (depth } \\
\text { sensing, body tracking) }\end{array}$ & Arm & Doctor Kinetic & Netherlands \\
\hline IREX & NI & Motion sensing with webcam & Arm & $\begin{array}{l}\text { GestureTek } \\
\text { Health }\end{array}$ & Canada \\
\hline Virtual Rehab & NI & $\begin{array}{l}\text { Motion-sensing camera (depth } \\
\text { sensing, body tracking, and } \\
\text { hand tracking) }\end{array}$ & Arm, hand & Evolv & Spain \\
\hline XR Health & I & HMD, controller & Arm & XR Health & USA \\
\hline iWall & NI & $\begin{array}{l}\text { Motion-sensing camera (depth } \\
\text { sensing, body tracking), } \\
\text { touch screen }\end{array}$ & Arm, hand & $\begin{array}{c}\text { CSE } \\
\text { Entertainment }\end{array}$ & Finland \\
\hline Nirvana & NI & wall or floor touch sensing & Arm, hand & $\begin{array}{c}\text { BTS } \\
\text { Bioengineering }\end{array}$ & USA \\
\hline Myro & NI & $\begin{array}{l}\text { Touch screen, touchable objects on } \\
\text { screen }\end{array}$ & Arm, hand & Tyromotion & USA \\
\hline DIEGO & $\mathrm{NI}$ & Hand suspended type & Arm & Tyromotion & USA \\
\hline AMADEO & NI & $\begin{array}{l}\text { Position and force sensor in hand } \\
\text { rehab robot }\end{array}$ & Finger & Tyromotion & USA \\
\hline Pablo & NI & IMU sensor & Arm, hand & Tyromotion & USA \\
\hline EsoGLOVE & NI & Hand exoskeleton & $\begin{array}{l}\text { Arm, hand, } \\
\text { finger }\end{array}$ & $\begin{array}{l}\text { Roceso } \\
\text { Technologies }\end{array}$ & Singapore \\
\hline Bimeo PRO & NI & $\begin{array}{l}\text { IMU sensor for body, IMU sensor } \\
\text { in objects }\end{array}$ & Arm, hand & Kinestica & Slovenia \\
\hline
\end{tabular}


Table 2. Cont.

\begin{tabular}{|c|c|c|c|c|c|}
\hline VR System & VR Type & Sensor Type & Body Part & Company & Country \\
\hline HandTutor & $\mathrm{NI}$ & Data glove & Hand, finger & Meditouch & Israel \\
\hline Playball & NI & IMU sensor in ball & Hand & Tonkey & Italy \\
\hline Anika & NI & Data glove & Hand, finger & ZARYA & Russia \\
\hline $\begin{array}{c}\text { Gloreha } \\
\text { Workstation } \\
\text { plus }\end{array}$ & NI & Hand exoskeleton, Optical sensor & Hand, finger & Gloreha & Italy \\
\hline Icone & NI & $\begin{array}{l}\text { Machine holding and } \\
\text { moving handle }\end{array}$ & Arm & Heaxel & Italy \\
\hline ExoRehab X & NI & Arm exoskeleton & Arm & HoustonBionic & Turkey \\
\hline Hand of Hope & NI & Hand exoskeleton & Hand, finger & $\begin{array}{l}\text { Rehab-Robotics } \\
\text { Company }\end{array}$ & Hong Kong \\
\hline SaeboRejoyce & NI & 3D movable handle & Arm, hand & Saebo & USA \\
\hline $\begin{array}{l}\text { MindMotion } \\
\text { Pro }\end{array}$ & NI & Colored object 3D tracking & Arm, hand & MindMaze & Switzerland \\
\hline YouGrabber & NI & $\begin{array}{c}\text { Data glove, infrared tracking } \\
\text { camera }\end{array}$ & $\begin{array}{l}\text { Arm, hand, } \\
\text { finger }\end{array}$ & YouRehab & Switzerland \\
\hline $\begin{array}{c}\text { Rapel Smart } \\
\text { Glove }\end{array}$ & NI & Data glove, IMU sensor & $\begin{array}{l}\text { Arm, hand, } \\
\text { finger }\end{array}$ & Neofect & South Korea \\
\hline Smartboard & NI & 2D handling board & Arm & Neofect & South Korea \\
\hline MusicGlove & NI & Finger-to-finger contact & Finger & FlintRehab & USA \\
\hline FitMi & NI & $\begin{array}{l}\text { Puck with multiple sensors for } \\
\text { movement tracking }\end{array}$ & Arm, hand & FlintRehab & USA \\
\hline SensoRehab & $\mathrm{NI}$ & Data glove & Hand, finger & SensoMed & Russia \\
\hline Rewellio & I & HMD, controller & Arm & Rewellio Inc. & USA \\
\hline
\end{tabular}

\section{Clinical Evidence and Considerations for VR in Motor Rehabilitation after Stroke}

\subsection{Literature Search}

Studies for upper limb VR rehabilitation after stroke were identified by an online search of Ovid-MEDLINE, Ovid-EMBASE, the Cochrane Library, and KoreaMed on 18 June 2020. The search queries are presented in Supplementary Table S1. Titles and abstracts were reviewed for screening by Y.K. and non-English papers, animal studies, commentaries, case series, narratives, book chapters, editorials, nonsystematic reviews, and conference papers were excluded. Duplicated publications between databases were also excluded. A total of 339 studies were included for the full text review and Y.K. and W.S.K. selected systematic reviews and meta-analyses for review. Six meta-analyses were included for our evidence summary [63-68].

\subsection{Clinical Evidence}

The general characteristics of the included meta-analyses are presented in Table 3. Two studies included randomized controlled trials (RCTs) and quasi-randomized controlled trials $[64,68]$ and three other studies only included RCTs $[63,65,67]$. Karamians et al. included RCTs and prospective studies [66]. The number of studies and participants included in each meta-analysis ranged from 21 to 72 and 562 to 2470 , respectively. 
Table 3. Characteristics of the included meta-analyses.

\begin{tabular}{|c|c|c|c|c|c|c|}
\hline Study & Aim & Search Strategy & Search Period & Inclusion Criteria & Included Trials, $n$ & Participants, $n$ \\
\hline Lohse et al., 2014 [64] & $\begin{array}{l}\text { To demonstrate the effect of virtual } \\
\text { reality (VR) therapy among patients } \\
\text { after stroke in both custom built virtual } \\
\text { environments and commercial } \\
\text { gaming systems. }\end{array}$ & $\begin{array}{c}\text { MEDLINE, CINAHL, } \\
\text { EMBASE, ERIC, PSYCInfo, } \\
\text { DARE, PEDro, Cochrane, } \\
\text { Central Register of Controlled } \\
\text { Trials, and Cochrane Database } \\
\text { of Systematic Reviews } \\
\end{array}$ & $\begin{array}{l}\text { From inception to } 4 \\
\quad \text { April } 2013\end{array}$ & $\begin{array}{c}\text { Randomized or } \\
\text { quasi-randomized controlled } \\
\text { trials with adults (>18 years } \\
\text { old) after stroke, excluding } \\
\text { other neurological disorders. }\end{array}$ & 24 & 626 \\
\hline Laver et al., 2017 [68] & $\begin{array}{l}\text { To investigate the efficacy of VR in } \\
\text { comparison with alternative } \\
\text { interventions or no interventions on the } \\
\text { function and activity of hemiparetic } \\
\text { upper limbs. }\end{array}$ & $\begin{array}{l}\text { Cochrane Stroke Group Trials } \\
\text { Register, CENTRAL, } \\
\text { MEDLINE, Embase, and seven } \\
\text { additional databases }\end{array}$ & $\begin{array}{l}\text { From inception to } \\
\quad \text { April } 2017\end{array}$ & $\begin{array}{l}\text { Randomized and } \\
\text { quasi-randomized trials of VR } \\
\text { rehabilitation in adults } \\
\text { after stroke. }\end{array}$ & 72 & 2470 \\
\hline Aminov et al., 2018 [63] & $\begin{array}{l}\text { To review the evidence for VR in upper } \\
\text { limb function and cognition after stroke. }\end{array}$ & $\begin{array}{l}\text { Scopus, Cochrane Database, } \\
\text { CINAHL, The Allied and } \\
\text { Complementary Medicine } \\
\text { Database, Web of Science, } \\
\text { MEDLINE, Pre-Medline, } \\
\text { PsycEXTRA, and PsycINFO } \\
\end{array}$ & $\begin{array}{l}\text { From inception to } 28 \\
\text { June } 2017\end{array}$ & $\begin{array}{l}\text { Randomized controlled trials } \\
\text { utilizing a VR to improve either } \\
\text { motor (upper limb) function, } \\
\text { cognitive, or activities of daily } \\
\text { living in patients with stroke. }\end{array}$ & 31 & 971 \\
\hline Lee et al., 2019 [67] & $\begin{array}{l}\text { To evaluate the effect of VR training on } \\
\text { lower limb, upper limb, and overall } \\
\text { functions in patients with chronic stroke. }\end{array}$ & OVID, PubMed, and EMBASE & $\begin{array}{l}\text { From January } 2000 \text { to } \\
\text { June } 2018\end{array}$ & $\begin{array}{l}\text { Randomized controlled trials } \\
\text { for using VR as a rehabilitation } \\
\text { intervention in patients with } \\
\text { chronic stroke. }\end{array}$ & 21 & 562 \\
\hline Karamians et al., 2020 [66] & $\begin{array}{l}\text { To demonstrate the efficacy of VR- and } \\
\text { gaming-based rehabilitations for upper } \\
\text { limb function in patients with stroke. }\end{array}$ & $\begin{array}{c}\text { PubMed, CINAHL/EBSCO, } \\
\text { SCOPUS, Ovid MEDLINE, and } \\
\text { EMBASE }\end{array}$ & From 2005 to 2019 & $\begin{array}{l}\text { Randomized controlled trials } \\
\text { or prospective study design } \\
\text { with outcome measures of Wolf } \\
\text { Motor Function Test, } \\
\text { Fugl-Meyer Assessment or } \\
\text { Action Research Arm Test in } \\
\text { patients who had poststroke } \\
\text { upper extremity deficits. }\end{array}$ & 38 & 1198 \\
\hline Mekbib et al., 2020 [65] & $\begin{array}{l}\text { To evaluate the therapeutic effect of VR } \\
\text { compared to dose-matched conventional } \\
\text { therapy in patients with stroke. }\end{array}$ & $\begin{array}{l}\text { EMBASE, MEDLINE, PubMed, } \\
\text { and Web of Science }\end{array}$ & $\begin{array}{l}\text { From } 2010 \text { to } \\
\text { February } 2019\end{array}$ & $\begin{array}{l}\text { Randomized controlled trials } \\
\text { that allocated patients either to } \\
\text { a VR therapy or to a } \\
\text { dose-matched } \\
\text { conventional therapy. }\end{array}$ & 27 & 1094 \\
\hline
\end{tabular}


Table 4. Review of findings of included meta-analyses.

\begin{tabular}{|c|c|c|c|c|c|c|}
\hline Study & Intervention & Comparison & Outcomes & Major Findings & Conclusions & Methodological Quality \\
\hline Lohse et al., 2014 [64] & $\begin{array}{l}\text { VR therapy: } \\
\text { Custom-built VE or } \\
\text { CG }\end{array}$ & $\mathrm{CT}$ & $\begin{array}{l}\text { Behavioral } \\
\text { assessment in body } \\
\text { function, activity, or } \\
\text { participation } \\
\text { according to } \\
\text { International } \\
\text { Classification of } \\
\text { Functioning (ICF) }\end{array}$ & $\begin{array}{c}\text { (1) Body function } \\
\text {-VE: } \mathrm{SMD}=0.43,95 \% \mathrm{CI}=0.22 \text { to } 0.64 \\
\text {-CG: } \mathrm{SMD}=0.76,95 \% \mathrm{CI}=-0.17 \text { to } 1.70 \\
\text { (2) Activity } \\
\text {-VE: } \mathrm{SMD}=0.54,95 \% \mathrm{CI}=0.28 \text { to } 0.81 \\
\text {-CG: } \mathrm{SMD}=0.76,95 \% \mathrm{CI}=-0.25 \text { to } 1.76 \\
\text { (3) Participation } \\
\text {-VE: } \mathrm{SMD}=0.56,95 \% \mathrm{CI}=0.02 \text { to } 1.10\end{array}$ & $\begin{array}{l}\text { VR rehabilitation moderately improves } \\
\text { functional outcomes compared to CT in } \\
\text { patients with stroke. CG studies were } \\
\text { too few and small to evaluate the } \\
\text { benefits of CG. }\end{array}$ & High \\
\hline Laver et al., 2017 [68] & VR rehabilitation & $\begin{array}{l}\text { Alternative } \\
\text { intervention (usually } \\
\text { CT) or no intervention }\end{array}$ & $\begin{array}{l}\text { Upper limb function } \\
\text { and activity }\end{array}$ & $\begin{array}{c}\text { (1) Upper limb function (VR versus CT) } \\
\text {-Composite: } \mathrm{SMD}=0.07,95 \% \mathrm{CI}=-0.05 \text { to } 0.20 \\
\text {-FMA: } \mathrm{SMD}=2.85,95 \% \mathrm{CI}=1.06 \text { to } 4.65 \\
\text { (2) Upper limb function (additional VR) } \\
\text {-Composite: } \mathrm{SMD}=0.49,95 \mathrm{CI}=0.21 \text { to } 0.77 \\
\text { (3) Activity of daily living } \\
\text {-VR versus } \mathrm{CT} \\
: \mathrm{SMD}=0.25,95 \% \mathrm{CI}=0.06 \text { to } 0.43 \\
\text {-Additional VR } \\
: \mathrm{SMD}=0.44,95 \% \mathrm{CI}=0.11 \text { to } 0.76\end{array}$ & $\begin{array}{l}\text { VR rehabilitation was not superior to CT } \\
\text { in improving upper limb function. VR } \\
\text { may be beneficial, when applied as an } \\
\text { additional therapy to usual care, to } \\
\text { improve the function of hemiparetic } \\
\text { upper limbs and activities of daily living } \\
\text { as additional VR therapy can increase } \\
\text { overall therapy time. }\end{array}$ & High \\
\hline $\begin{array}{c}\text { Aminov et al., } 2018 \\
\text { [63] }\end{array}$ & VR rehabilitation & CT & $\begin{array}{l}\text { Upper limb function } \\
\text { (e.g., FMA) and } \\
\text { activity (e.g., BBT, BI) } \\
\text { according to ICF }\end{array}$ & $\begin{array}{c}\text { (1) Upper limb function } \\
: \mathrm{SMD}=0.41,95 \% \mathrm{CI}=0.28 \text { to } 0.55 \\
\text { (2) Upper limb activity } \\
: \mathrm{SMD}=0.47,95 \% \mathrm{CI}=0.34 \text { to } 0.60\end{array}$ & $\begin{array}{l}\text { VR can be beneficial on outcomes of } \\
\text { body structure/function and activity in } \\
\text { patients with stroke. }\end{array}$ & Moderate \\
\hline Lee et al., 2019 [67] & VR rehabilitation & $\mathrm{CT}$ or no intervention & Upper limb function & $\begin{array}{c}\text { (1) Upper limb function } \\
: \mathrm{SMD}=0.43,95 \% \mathrm{CI}=0.42 \text { to } 0.54 \\
\text { (2) } \mathrm{Lower} \text { limb function } \\
: \mathrm{SMD}=0.42,95 \% \mathrm{CI}=0.34 \text { to } 0.51 \\
\text { (3) Overall function } \\
: \mathrm{SMD}=0.55,95 \% \mathrm{CI}=0.25 \text { to } 0.84\end{array}$ & $\begin{array}{l}\text { VR training moderately improved } \\
\text { function in patients with chronic stroke. }\end{array}$ & Low \\
\hline $\begin{array}{c}\text { Karamians et al., } 2020 \\
\text { [66] }\end{array}$ & VR rehabilitation & $\mathrm{CT}$ or no intervention & $\begin{array}{l}\text { Upper limb function } \\
\text { (FMA, WMFT, ARAT) }\end{array}$ & $\begin{array}{l}\text { (1) VR or gaming versus all controls } \\
\text { : Percent possible improvement } \\
=28.45 \%, 95 \% \mathrm{CI}=24.40 \text { to } 32.49 \% \\
\text { (2) VR or gaming versus } \mathrm{CT} \\
\text { : Percent possible improvement } \\
=10.40 \%, 95 \% \mathrm{CI}=5.65 \text { to } 15.14 \%\end{array}$ & $\begin{array}{l}\text { VR- or gaming-based rehabilitation for } \\
\text { upper limb function was more effective } \\
\text { than CT in patients with stroke. }\end{array}$ & Moderate \\
\hline $\begin{array}{l}\text { Mekbib et al., } 2020 \\
\text { [65] }\end{array}$ & VR rehabilitation & Dose-matched CT & $\begin{array}{l}\text { Upper limb function } \\
\text { (FMA, BBT, MAL) }\end{array}$ & 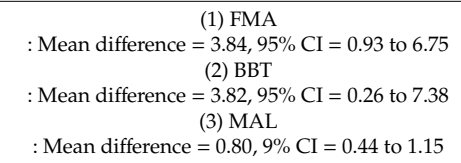 & $\begin{array}{l}\text { VR rehabilitation was more beneficial on } \\
\text { post-stroke upper limb function in the } \\
\text { outcomes of FMA, BBT and MAL than } \\
\text { dose-matched CT. }\end{array}$ & Moderate \\
\hline
\end{tabular}

VR rehabilitation includes both rehabilitations using custom-built virtual environments and commercial video gaming consoles (e.g., Nintendo Wii or Xbox Kinect). FMA, BBT, WMFT, ARAT, and MAL are the measurement tools for upper limb function. Abbreviations: VR, virtual reality; VE, virtual environments; CG, commercially available gaming systems; CT, conventional therapy; ICF, International Classification of Functioning; SMD, standardized mean difference; CI, confidence interval; FMA, Fugl-Meyer Assessment; BBT, Box and Block Test; BI, Barthel Index; WMFT, Wolf Motor Function Test; ARAT, Action Research Arm Test; MAL, Motor Activity Log. 
The interventions were VR rehabilitation and the controls were either conventional therapy (dose-matched or not) or no intervention (Table 4). VR rehabilitation included rehabilitations using both custom-built virtual environments and commercial video gaming consoles (e.g., Nintendo Wii or Xbox Kinect) in the selected meta-analyses. Outcomes were usually the composite outcomes of upper limb function or activities and Karamians et al. only included studies using one of the following outcome measures: Fugl-Meyer Assessment (FMA), Wolf Motor Function Test (WMFT), and Action Research Arm Test (ARAT) [66]. Mekbib et al. only included studies using one of the three following outcomes: FMA, Box and Block Test (BBT), and Motor Activity Log (MAL) [65]. Methodological quality of the included meta-analyses was assessed using the Assessment of Multiple Systematic Reviews (AMSTAR 2) instrument by two authors (S.C. and W.S.K.) and was categorized as high, moderate, low, or critically low [69]. Any disagreements were resolved through the discussion for consensus. Most of the included meta-analyses showed moderate to high methodological quality (Table 4).

In one high-quality meta-analysis from 2014, VR rehabilitation showed better improvements in body function (standardized mean difference $(\mathrm{SMD})=0.43,95 \%$ confidence interval $(\mathrm{CI})=0.22$ to 0.64 ) and activities (SMD $=0.54,95 \% \mathrm{CI}=0.28$ to 0.81 ) when compared to conventional therapy [64]. However, the commercially available gaming failed to show a significant beneficial effect due to the small number of studies (Table 4). In a recent Cochrane systematic review with high methodological quality, VR rehabilitation for the composite outcome of upper limb function (primary outcome) was not superior to conventional therapy, but upper limb function measured by FMA was significantly improved in VR rehabilitation ( $\mathrm{SMD}=2.85,95 \% \mathrm{CI}=1.06$ to 4.65) [68]. When VR rehabilitation was applied in addition to conventional therapy, VR rehabilitation showed significant beneficial effects on the composite outcome of upper limb function ( $\mathrm{SMD}=0.49,95 \mathrm{CI}=0.21$ to 0.77 ). Two metanalyses by Aminov et al. [63] and Lee et al. [67] also showed similar moderate effect sizes for upper limb function in VR rehabilitation (Table 4). Mekbib et al. [65] only included RCTs using dose-matched conventional therapy and calculated the mean differences of FMA, BBT, and MAL, which all represent upper limb function. Although VR showed better improvements in all outcomes when compared to conventional therapy, they were less than the minimal clinically important difference $[70,71]$.

\section{Considerations for VR Application in Stroke Rehabilitation}

\subsection{HMDs and Motion Sickness}

HMDs give users a more immersive experience in a 3D artificial world and allow interaction with virtual objects using motion tracking sensors. Considering the therapy time and active motion during the rehabilitation, the HMD must be light, comfortable to wear, positioned stably on the head, and cool enough during operation (HMD typically generate heat). The HMD may also benefit from being wireless (with enough battery life). Although VR rehabilitation can induce eye strain or physical fatigue during extended therapy, the most common issue to overcome is motion sickness. Motion sickness can be elicited when there is a lag in processing the visual response to user input interactions, resulting in conflicting signals to the brain from the eyes, vestibular systems in the inner ear, and proprioceptive sensory receptors (sensory conflict theory) [72]. Motion sickness can be affected by the system (e.g., head tracking, rendering, field of view, optics); application and user interaction (lack of controlling visual motion, visual acceleration or deceleration, longer duration of VR experience, frequent head movement during VR play); and individual perceptual factors (age, motion sickness history, lack of VR experience). The following approaches can be employed to reduce motion sickness when designing VR rehabilitation programs [73]: "(1) to make patients actively control their view points and be responsible for initiating movement, (2) to avoid or limit linear or angular accelerations or decelerations without corresponding vestibular stimulation, (3) to display visual indicators or motion trajectories, (4) to display visual cues that remain stable as the patient moves, and (5) to perform dynamic blurring of unimportant areas." 


\subsection{Differences in Movements in VR}

The movement kinematics of the upper limb in patients with stroke differ between VR and real environments. Viau et al. reported that patients with hemiparesis used less wrist extension and more elbow extension at the end of the placing phase during reaching, grasping, and performing tasks in VR than in a real environment [74]. Similarly, several studies using reaching tasks also demonstrated that the movements in VR using HMDs were slower than those in the real environment and that spatial and temporal kinematics differ between VR and real environments [75-77]. Lott et al. reported that the range of the center of pressure during reaching in standing (usually used for balance training) was different between real environments, non-immersive VR with 2D flat-screen displays, and immersive VR with HMDs [78]. Considering the rehabilitation purpose of improving independence in real-world living, these different movement kinematics can affect the transfer of learning in VR to real environments and therefore must be considered when designing a VR-based rehabilitation program.

\subsection{Transfer of Learning in VR to the Real World}

The transfer of improved function after rehabilitation to the performance of activities of daily living is important in upper limb rehabilitation after stroke. Constraint-induced movement therapy (CIMT) comprises repetitive tasks/shaping practice with constraint of the hemiparetic upper limb, emphasizing the transfer package to foster compliance and use of the hemiparetic upper limb in the real world as a key component to improve function following CIMT [79]. Therefore, the transfer of novel rehabilitation therapeutic approaches based on repetitive movements to the real environment, such as robot-assisted arm rehabilitation [80] and VR-based rehabilitation [81], is an important issue to be discussed.

The transfer of learning effects in VR to real environments is inconclusive. Rose et al. showed that the effect of simple sensorimotor task training is comparable between VR and real environments [82]. However, several recent studies have shown that training in VR did not translate to better performance in the real environment [83-86]. In the virtual BBT simulated using a 2D flat screen and depth-sensing camera, the number of boxes moved in VR showed good correlation (a high correlation coefficient) with that in the real BBT, but the actual number of boxes moved was much less in the VR condition [33]. The weak transfer of effects from VR to real environments may be associated with different sensory-motor symptoms and spatiotemporal organization, especially the differences in depth perception in VR during upper limb rehabilitation (reach, touch, grasp, and release tasks). Although an HMD improves depth perception compared to a 2D flat screen display [87], further improvements in VR depth perception, and thereby fidelity, is needed. Possible strategies include object occlusion; effects of lighting and shadow; color shading; and relative scaling of objects by considering depth, perspective projection, and motion parallax [88]. Other methods to improve the interaction can be visual (e.g., color change) or auditory feedback when touching objects in VR. Haptic feedback can further improve the interaction and thereby the fidelity of the VR training. Ebrahimi et al. demonstrated that the errors and time to complete the task during reaching and pointing tasks using a stylus in immersive VR with a HMD were decreased with the addition of visuohaptic feedback compared to the condition without it [89]. It has also been suggested that matching the VR interaction dimensions with the control dimension of the task in the real world could improve the transfer of the VR rehabilitation effect [90].

\subsection{Gamification}

Gamification has been broadly and clearly defined as the "use of game design principles in non-game contexts" by Deterding et al. [91]. Gamification of VR-based rehabilitation systems can motivate patients to participate in rehabilitation actively with enjoyment, which could lead to more movements of the hemiparetic arm and better recovery [92]. The strategies to apply gamification to virtual rehabilitation design have been thoroughly reviewed by Charles et al. [88] and Mubin et al. [93]. 
Briefly, the VR rehabilitation system must give the patients clear feedback for meaningful play, such as the therapist's verbal and emotional encouragement, with a clear goal to be achieved during the occupational therapy. The difficulty level or challenge during the rehabilitation game should be adapted according to the patient's ability to facilitate meaningful play and handle failures $[94,95]$ as patients with stroke may experience multiple failures and can be frustrated during upper limb rehabilitation due to motor impairments. Various types of feedback, including visual, auditory, and haptic feedback, can be applied and approaches to possibly promote motor learning should be considered (inducing variability of tasks, amplification of visual errors, and manipulating task physics for implicit behavioral guidance) [81].

\subsection{Barriers}

In addition to the barriers caused by patients (physical and cognitive disabilities, low adoptability, and compliance to technology), it has been suggested that there are also barriers at the therapist level, which can lead to underuse of VR rehabilitation [96]. Glegg et al. recently reviewed the barriers and facilitators influencing the adoption of VR rehabilitation, which include "the ability to grade the degree of training, transfer of training to real life, knowledge about how to operate the VR clinically, therapist self-efficacy and perceived ease of use, technical and treatment space issues, access to the technology, and time to learn practice for VR rehabilitation" [97]. They gave three recommendations to promote the use of VR rehabilitation, which were "(1) enhance collaboration, (2) ensure knowledge transfer interventions are system- and context-specific, and (3) optimize VR effectiveness through an evidence-based approach" [97].

\section{Combinational Approaches with VR in Stroke Rehabilitation}

Neuroplasticity is the ability of the human brain to adapt to certain experiences, environments, and extreme changes, including brain damage [98-100]. Several novel therapeutic approaches to enhance neuroplasticity can be considered as combinational approaches to VR rehabilitation.

The brain-computer interface $(\mathrm{BCI})$ is one method used to improve neuroplasticity after stroke; it is based on motor imagery, which is defined as the mental simulation of a kinesthetic movement. The BCI provides sensory feedback of ongoing sensorimotor brain activities, thereby enabling stroke survivors to self-modulate their sensorimotor brain activities [101]. BCI for motor rehabilitation involves the recording and decoding of brain signals generated in the sensorimotor cortex areas. The recorded brain signals can be used (1) to objectify and strengthen motor imagery-based training by providing stroke patients with real-time feedback on an imagined motor task; (2) to generate a desired motor task by producing a command to control external rehabilitative tools, such as functional electrical stimulation, robotic orthoses attached to the patient's limb, or VR; and (3) to understand cerebral reorganizations of lesioned areas by quantifying plasticity-induced changes in brain networks and power spectra in motor-related frequency bands (i.e., alpha and beta) [102]. A previous meta-analysis reported that $\mathrm{BCI}$ had an SMD of 0.79 , which represented a medium to large effect size comparable with those of conventional rehabilitation therapy such as CIMT (SMD $=0.33$ ), mirror therapy (SMD $=0.61)$, and mental practice $(\mathrm{SMD}=0.62)$ [101]. Pichiorri et al. showed that BCI combined with VR may further improve upper limb rehabilitation outcomes and may be used to predict motor outcomes by analyzing brain activity in patients with stroke [103]. A more recent study also demonstrated the clinical feasibility of using a combination of $\mathrm{BCI}$ and VR in post-stroke motor rehabilitation and confirmed that this combinatory method may benefit patients with severe motor impairments who have little ability for volitional movement [104].

Another novel strategy to increase neuroplasticity using noninvasive brain stimulation, such as transcranial magnetic stimulation (TMS) and transcranial direct current stimulation (tDCS), has also been suggested by various researchers [105-107]. Noninvasive brain stimulation methods can be used to (1) enhance the ipsilesional brain activity by high-frequency rTMS [108] or anodal tDCS [109,110]; (2) inhibit contralesional brain activity by low-frequency rTMS [111,112] or cathodal tDCS [113]; (3) 
produce an additive effect by simultaneously applying anodal tDCS over the ipsilesional area and cathodal tDCS over the contralesional area, referred to as bihemispheric tDCS [114]; or (4) modulate the somatosensory input from nerve fibers to the brain $[115,116]$. These noninvasive brain stimulation methods have been reported to have acceptable tolerability and safety with no significant adverse effects in various populations, including patients with stroke $[117,118]$. Several studies have shown a positive effect of combinational approaches (noninvasive brain stimulation plus VR-based rehabilitation) in patients following stroke [119-121].

Together with BCI and noninvasive brain stimulation, a telerehabilitation approach may also be important for motor rehabilitation after stroke in terms of better accessibility and prolonged usage at home. Telerehabilitation, by definition, can provide the inputs of multidisciplinary skilled personnel for rehabilitation, including physiatrists, physiotherapists, and occupational therapists, which are often unavailable at home or challenged by transportation restrictions for disabled patients [122]. A recent Cochrane systematic review showed moderate-quality evidence that there was no difference in activities of daily living in patients with stroke between those who received telerehabilitation and those who received usual care (SMD $=-0.00,95 \% \mathrm{CI}=-0.15$ to 0.15 ) [123]. There was also low-quality evidence of no difference in upper limb functions between the use of a computer program to remotely retrain upper limb function and in-person therapy (mean difference $=1.23,95 \% \mathrm{CI}=-2.17$ to 4.64 ) [123]. Several studies have shown that VR based telerehabilitation can be used for motor rehabilitation of upper extremity functions with improvements in FMA of the upper extremity, Brunnstrom stage, manual muscle test, and action research arm test $[124,125]$.

\section{Summary}

VR-based rehabilitation is a promising tool to actively engage patients in the rehabilitation program and can lead to better motor recovery. Although current clinical evidence shows that VR-based rehabilitation is beneficial as an adjunct therapy to conventional rehabilitation therapy, the interventions in the studies included in the meta analyses were heterogeneous and it is unclear who benefits more from VR rehabilitation (e.g., severity of impairment, time since onset of stroke) and what type of VR (e.g., immersive vs. non-immersive) and feedback is more effective. Further research including large well-designed RCTs to find the factors influencing the effects of VR rehabilitation are required.

To improve the efficacy of VR-based rehabilitation, VR rehabilitation is designed to improve the transfer of VR training to real environments, gamification, and feedback to promote active patient participation and neuroplasticity is necessary. The user interface and user experience must be designed to be more user-friendly to patients and therapists, considering both the patient's physical and cognitive impairments and therapists' needs. VR can be integrated into novel therapeutic modalities that can enhance neuroplasticity (e.g., BCI and noninvasive brain stimulation) and is expected to induce better recovery by combinational approaches, which warrant further investigation.

Supplementary Materials: The following are available online at http:/www.mdpi.com/2077-0383/9/10/3369/s1, Table S1: Search queries for studies about upper limb virtual reality rehabilitation after stroke.

Author Contributions: W.-S.K., S.C., J.K., H.-J.H., and K.L. contributed to drafting this review. W.-S.K. conceived the framework. N.-J.P. provided guidance and assistance. Y.K. searched the articles for VR application for stroke rehabilitation. All authors reviewed the manuscript and contributed to the editing. All authors have read and agreed to the published version of the manuscript.

Funding: This work was supported by the Ministry of Trade Industry and Energy (Korea), Ministry of Science and Information and Communications Technology (Korea), and the Ministry of Health and Welfare (Korea) under the Technology Development Program for AI-Bio-Robot-Medicine Convergence (20001650) and by a grant from the Seoul National University Bundang Hospital (SNUBH) Research Fund (02-2016-032).

Conflicts of Interest: S.C. is the CEO of the company related to the VR-based rehabilitation system. W.-S.K. is the CMO of Delvine Inc. W.-S.K., S.C., J.K., and N.-J.P. have patents related to the VR-based rehabilitation system. W.-S.K., S.C., J.K., K.L., H.-J.H., and N.-J.P. are working for the project to develop a VR-based rehabilitation system, which has not been commercialized yet, supported by funds from the Technology Development Program for AI-Bio-Robot-Medicine Convergence (20001650). The other authors have no conflicts of interest to declare. 


\section{References}

1. Collaborators, G.S. Global, regional, and national burden of stroke, 1990-2016: A systematic analysis for the Global Burden of Disease Study 2016. Lancet Neurol. 2019, 18, 439-458.

2. Gorelick, P.B. The future of stroke prevention by risk factor modification. Handb. Clin. Neurol. 2009, 94, 1261-1276. [PubMed]

3. Ovbiagele, B.; Goldstein, L.B.; Higashida, R.T.; Howard, V.J.; Johnston, S.C.; Khavjou, O.A.; Lackland, D.T.; Lichtman, J.H.; Mohl, S.; Sacco, R.L.; et al. Forecasting the future of stroke in the United States: A policy statement from the American Heart Association and American Stroke Association. Stroke 2013, 44, 2361-2375. [CrossRef] [PubMed]

4. Lawrence, E.S.; Coshall, C.; Dundas, R.; Stewart, J.; Rudd, A.G.; Howard, R.; Wolfe, C.D. Estimates of the prevalence of acute stroke impairments and disability in a multiethnic population. Stroke 2001, 32, 1279-1284. [CrossRef]

5. Faria-Fortini, I.; Michaelsen, S.M.; Cassiano, J.G.; Teixeira-Salmela, L.F. Upper extremity function in stroke subjects: Relationships between the international classification of functioning, disability, and health domains. J. Hand Ther. 2011, 24, 257-264; quiz 265. [CrossRef]

6. Min, K.B.; Min, J.Y. Health-related quality of life is associated with stroke deficits in older adults. Age Ageing 2015, 44, 700-704. [CrossRef]

7. Kwon, S.; Park, J.H.; Kim, W.S.; Han, K.; Lee, Y.; Paik, N.J. Health-related quality of life and related factors in stroke survivors: Data from Korea National Health and Nutrition Examination Survey (KNHANES) 2008 to 2014. PLOS ONE 2018, 13, e0195713. [CrossRef]

8. Winstein, C.J.; Stein, J.; Arena, R.; Bates, B.; Cherney, L.R.; Cramer, S.C.; Deruyter, F.; Eng, J.J.; Fisher, B.; Harvey, R.L.; et al. Guidelines for Adult Stroke Rehabilitation and Recovery: A Guideline for Healthcare Professionals from the American Heart Association/American Stroke Association. Stroke 2016, 47, e98-e169. [CrossRef]

9. Lohse, K.R.; Lang, C.E.; Boyd, L.A. Is more better? Using metadata to explore dose-response relationships in stroke rehabilitation. Stroke 2014, 45, 2053-2058. [CrossRef]

10. Barreca, S.; Wolf, S.L.; Fasoli, S.; Bohannon, R. Treatment interventions for the paretic upper limb of stroke survivors: A critical review. Neurorehabil. Neural Repair 2003, 17, 220-226. [CrossRef]

11. Levin, M.F.; Weiss, P.L.; Keshner, E.A. Emergence of virtual reality as a tool for upper limb rehabilitation: Incorporation of motor control and motor learning principles. Phys. Ther. 2015, 95, 415-425. [CrossRef] [PubMed]

12. Kleim, J.A.; Jones, T.A. Principles of experience-dependent neural plasticity: Implications for rehabilitation after brain damage. J. Speech Lang. Hear. Res. 2008, 51, S225-S239. [CrossRef]

13. Merians, A.S.; Jack, D.; Boian, R.; Tremaine, M.; Burdea, G.C.; Adamovich, S.V.; Recce, M.; Poizner, H. Virtual reality-augmented rehabilitation for patients following stroke. Phys. Ther. 2002, 82, 898-915. [CrossRef] [PubMed]

14. Burke, J.W.; McNeill, M.; Charles, D.K.; Morrow, P.J.; Crosbie, J.H.; McDonough, S.M. Optimising engagement for stroke rehabilitation using serious games. Vis. Comput. 2009, 25, 1085. [CrossRef]

15. Mihelj, M.; Novak, D.; Milavec, M.; Ziherl, J.; Olenšek, A.; Munih, M. Virtual rehabilitation environment using principles of intrinsic motivation and game design. Presence Teleoperators Virtual Environ. 2012, 21, 1-15. [CrossRef]

16. Kim, W.S.; Cho, S.; Park, S.H.; Lee, J.Y.; Kwon, S.; Paik, N.J. A low cost kinect-based virtual rehabilitation system for inpatient rehabilitation of the upper limb in patients with subacute stroke: A randomized, double-blind, sham-controlled pilot trial. Medicine 2018, 97, e11173. [CrossRef]

17. Holden, M.K.; Dyar, T.A.; Dayan-Cimadoro, L. Telerehabilitation using a virtual environment improves upper extremity function in patients with stroke. IEEE Trans. Neural Syst. Rehabil Eng. 2007, 15, 36-42. [CrossRef]

18. Kim, W.S.; Cho, S.; Baek, D.; Bang, H.; Paik, N.J. Upper Extremity Functional Evaluation by Fugl-Meyer Assessment Scoring Using Depth-Sensing Camera in Hemiplegic Stroke Patients. PLoS ONE 2016, 11, e0158640. [CrossRef]

19. Slater, M.; Wilbur, S. A Framework for Immersive Virtual Environments (FIVE): Speculations on the Role of Presence in Virtual Environments. Presence Teleoperators Virtual Environ. 1997, 6, 603-616. [CrossRef] 
20. Slater, M. Place illusion and plausibility can lead to realistic behaviour in immersive virtual environments. Philos. Trans. R. Soc. Lond. B Biol. Sci. 2009, 364, 3549-3557. [CrossRef]

21. Bailey, J.O.; Bailenson, J.N. When Does Virtual Embodiment Change Our Minds? Presence Teleoperators Virtual Environ. 2016, 25, 222-233. [CrossRef]

22. Ventura, S.; Brivio, E.; Riva, G.; Banos, R.M. Immersive Versus Non-immersive Experience: Exploring the Feasibility of Memory Assessment through 360 degrees Technology. Front. Psychol. 2019, 10, 2509. [CrossRef] [PubMed]

23. Czernuszenko, M.; Pape, D.; Sadin, D.; DeFanti, T.; Dawe, G.L.; Brown, M.D. The ImmersaDesk and infinity wall projection-based virtual reality displays. ACM Siggraph Comput. Graph. 1997, 31, 46-59. [CrossRef]

24. Cruz-Neira, C.; Sandin, D.J.; DeFanti, T.A.; Kenyon, R.V.; Hart, J.C. The CAVE: Audio visual experience automatic virtual environment. Commun. ACM 1992, 35, 64-72. [CrossRef]

25. Kober, S.E.; Kurzmann, J.; Neuper, C. Cortical correlate of spatial presence in 2D and 3D interactive virtual reality: An EEG study. Int. J. Psychophysiol. 2012, 83, 365-374. [CrossRef]

26. Wirth, W.; Hartmann, T.; Böcking, S.; Vorderer, P.; Klimmt, C.; Schramm, H.; Saari, T.; Laarni, J.; Ravaja, N.; Gouveia, F.R.; et al. A Process Model of the Formation of Spatial Presence Experiences. Media Psychol. 2007, 9, 493-525. [CrossRef]

27. Lloréns, R.; Noé, E.; Naranjo, V.; Borrego, A.; Latorre, J.; Alcañiz, M. Tracking systems for virtual rehabilitation: Objective performance vs. subjective experience. A practical scenario. Sensors 2015, 15, 6586-6606. [CrossRef]

28. Juo, Y.-Y.; Abiri, A.; Pensa, J.; Sun, S.; Tao, A.; Bisley, J.; Grundfest, W.; Dutson, E. Center for Advanced Surgical and Interventional Technology Multimodal Haptic Feedback for Robotic Surgery. In Handbook of Robotic and Image-Guided Surgery; Abedin-Nasab, M.H., Ed.; Elsevier: Amsterdam, The Netherlands, 2020; pp. 285-301.

29. Dimbwadyo-Terrer, I.; Trincado-Alonso, F.; de Los Reyes-Guzman, A.; Aznar, M.A.; Alcubilla, C.; Perez-Nombela, S.; Del Ama-Espinosa, A.; Polonio-Lopez, B.; Gil-Agudo, A. Upper limb rehabilitation after spinal cord injury: A treatment based on a data glove and an immersive virtual reality environment. Disabil. Rehabil. Assist. Technol. 2016, 11, 462-467. [CrossRef]

30. Crosbie, J.H.; Lennon, S.; McGoldrick, M.C.; McNeill, M.D.; McDonough, S.M. Virtual reality in the rehabilitation of the arm after hemiplegic stroke: A randomized controlled pilot study. Clin. Rehabil. 2012, 26, 798-806. [CrossRef]

31. Calabrò, R.S.; Accorinti, M.; Porcari, B.; Carioti, L.; Ciatto, L.; Billeri, L.; Andronaco, V.A.; Galletti, F.; Filoni, S.; Naro, A. Does hand robotic rehabilitation improve motor function by rebalancing interhemispheric connectivity after chronic stroke? Encouraging data from a randomised-clinical-trial. Clin. Neurophysiol. 2019, 130, 767-780. [CrossRef]

32. Kiper, P.; Szczudlik, A.; Agostini, M.; Opara, J.; Nowobilski, R.; Ventura, L.; Tonin, P.; Turolla, A. Virtual Reality for Upper Limb Rehabilitation in Subacute and Chronic Stroke: A Randomized Controlled Trial. Arch. Phys. Med. Rehabil. 2018, 99, 834-842.e4. [CrossRef] [PubMed]

33. Cho, S.; Kim, W.-S.; Paik, N.-J.; Bang, H. Upper-Limb Function Assessment Using VBBTs for Stroke Patients. IEEE Comput. Graph. Appl. 2016, 36, 70-78. [CrossRef] [PubMed]

34. Askin, A.; Atar, E.; Kocyigit, H.; Tosun, A. Effects of Kinect-based virtual reality game training on upper extremity motor recovery in chronic stroke. Somatosens. Mot. Res. 2018, 35, 25-32. [CrossRef] [PubMed]

35. Faria, A.L.; Cameirao, M.S.; Couras, J.F.; Aguiar, J.R.O.; Costa, G.M.; Bermudez, I.B.S. Combined Cognitive-Motor Rehabilitation in Virtual Reality Improves Motor Outcomes in Chronic Stroke-A Pilot Study. Front. Psychol. 2018, 9, 854. [CrossRef]

36. Lee, M.M.; Lee, K.J.; Song, C.H. Game-Based Virtual Reality Canoe Paddling Training to Improve Postural Balance and Upper Extremity Function: A Preliminary Randomized Controlled Study of 30 Patients with Subacute Stroke. Med. Sci. Monit. Int. Med. J. Exp. Clin. Res. 2018, 24, 2590-2598. [CrossRef]

37. Sucar, L.E.; Orihuela-Espina, F.; Velazquez, R.L.; Reinkensmeyer, D.J.; Leder, R.; Hernandez-Franco, J. Gesture therapy: An upper limb virtual reality-based motor rehabilitation platform. IEEE Trans. Neural Syst. Rehabil. Eng. 2014, 22, 634-643. [CrossRef]

38. Ballester, B.R.; Nirme, J.; Camacho, I.; Duarte, E.; Rodríguez, S.; Cuxart, A.; Duff, A.; Verschure, P.F.M.J. Domiciliary VR-Based Therapy for Functional Recovery and Cortical Reorganization: Randomized Controlled Trial in Participants at the Chronic Stage Post Stroke. JMIR Serious Games 2017, 5, e15. [CrossRef] 
39. Sampson, M.; Shau, Y.W.; King, M.J. Bilateral upper limb trainer with virtual reality for post-stroke rehabilitation: Case series report. Disabil. Rehabil. Assist. Technol. 2012, 7, 55-62. [CrossRef]

40. Xin, W.; Duan, F.; Yong, Y.; Tan, J.T.C.; Xiaomin, C. Design of A Multi-functional System Based on Virtual Reality for Stroke Rehabilitation. In Proceedings of the 11th World Congress on Intelligent Control and Automation, Shenyang, China, 29 June-4 July 2014; pp. 2412-2417.

41. Feintuch, U.; Raz, L.; Hwang, J.; Josman, N.; Katz, N.; Kizony, R.; Rand, D.; Rizzo, A.S.; Shahar, M.; Yongseok, J.; et al. Integrating haptic-tactile feedback into a video-capture-based virtual environment for rehabilitation. Cyberpsychol. Behav. Impact Internetmultimedia Virtual Real. Behav. Soc. 2006, 9, 129-132. [CrossRef]

42. Popescu, V.G.; Burdea, G.C.; Bouzit, M.; Hentz, V.R. A virtual-reality-based telerehabilitation system with force feedback. IEEE Trans. Inf. Technol. Biomed. A Publ. IEEE Eng. Med. Biol. Soc. 2000, 4, 45-51. [CrossRef]

43. Prisco, G.M.; Avizzano, C.A.; Calcara, M.; Ciancio, S.; Pinna, S.; Bergamasco, M. A virtual environment with haptic feedback for the treatment of motor dexterity disabilities. In Proceedings of the 1998 IEEE International Conference on Robotics and Automation (Cat. No.98CH36146), Leuven, Belgium, 20 May 1998; Volume 4, pp. 3721-3726.

44. Alamri, A.; Eid, M.; Iglesias, R.; Shirmohammadi, S.; Saddik, A.E. Haptic Virtual Rehabilitation Exercises for Poststroke Diagnosis. IEEE Trans. Instrum. Meas. 2008, 57, 1876-1884. [CrossRef]

45. Kayyali, R.; Shirmohammadi, S.; Saddik, A.E.; Lemaire, E. Daily-Life Exercises for Haptic Motor Rehabilitation. In Proceedings of the 2007 IEEE International Workshop on Haptic, Audio and Visual Environments and Games, Ottawa, ON, Canada, 12-14 October 2007; pp. 118-123.

46. Adamovich, S.V.; Fluet, G.G.; Mathai, A.; Qiu, Q.; Lewis, J.; Merians, A.S. Design of a complex virtual reality simulation to train finger motion for persons with hemiparesis: A proof of concept study. J. Neuroeng. Rehabil. 2009, 6, 28. [CrossRef] [PubMed]

47. Molier, B.I.; Prange, G.B.; Krabben, T.; Stienen, A.H.; van der Kooij, H.; Buurke, J.H.; Jannink, M.J.; Hermens, H.J. Effect of position feedback during task-oriented upper-limb training after stroke: Five-case pilot study. J. Rehabil. Res. Dev. 2011, 48, 1109-1118. [CrossRef] [PubMed]

48. Jack, D.; Boian, R.; Merians, A.S.; Tremaine, M.; Burdea, G.C.; Adamovich, S.V.; Recce, M.; Poizner, H. Virtual reality-enhanced stroke rehabilitation. IEEE Trans. Neural Syst. Rehabil. Eng. 2001, 9, 308-318. [CrossRef]

49. Wille, D.; Eng, K.; Holper, L.; Chevrier, E.; Hauser, Y.; Kiper, D.; Pyk, P.; Schlegel, S.; Meyer-Heim, A. Virtual reality-based paediatric interactive therapy system (PITS) for improvement of arm and hand function in children with motor impairment-A pilot study. Dev. Neurorehabilit. 2009, 12, 44-52. [CrossRef]

50. Connelly, L.; Stoykov, M.E.; Jia, Y.; Toro, M.L.; Kenyon, R.V.; Kamper, D.G. Use of a pneumatic glove for hand rehabilitation following stroke. In Proceedings of the 2009 Annual International Conference of the IEEE Engineering in Medicine and Biology Society, Minneapolis, MN, USA, 3-6 September 2009; pp. 2434-2437.

51. Huang, X.; Naghdy, F.; Naghdy, G.; Du, H. Clinical effectiveness of combined virtual reality and robot assisted fine hand motion rehabilitation in subacute stroke patients. In Proceedings of the 2017 International Conference on Rehabilitation Robotics (ICORR), London, UK, 17-20 July 2017; pp. 511-515.

52. Pignolo, L.; Dolce, G.; Basta, G.; Lucca, L.F.; Serra, S.; Sannita, W.G. Upper limb rehabilitation after stroke: ARAMIS a "robo-mechatronic" innovative approach and prototype. In Proceedings of the 2012 th IEEE RAS \& EMBS International Conference on Biomedical Robotics and Biomechatronics (BioRob), Rome, Italy, 24-27 June 2012; pp. 1410-1414.

53. Andaluz, V.H.; Salazar, P.J.; Silva, S.M.; Escudero, V.M.; Bustamante, D.C. Rehabilitation of upper limb with force feedback. In Proceedings of the 2016 IEEE International Conference on Automatica (ICA-ACCA), Curico, Chile, 19-21 October 2016; pp. 1-6.

54. Bardorfer, A.; Munih, M.; Zupan, A.; Primozic, A. Upper limb motion analysis using haptic interface. IEEE/ASME Trans. Mechatron. 2001, 6, 253-260. [CrossRef]

55. Broeren, J.; Rydmark, M.; Sunnerhagen, K.S. Virtual reality and haptics as a training device for movement rehabilitation after stroke: A single-case. Arch. Phys. Med. Rehabil. 2004, 85, 1247-1250. [CrossRef]

56. Adamovich, S.V.; Fluet, G.G.; Merians, A.S.; Mathai, A.; Qiu, Q. Incorporating Haptic Effects Into Three-Dimensional Virtual Environments to Train the Hemiparetic Upper Extremity. IEEE Trans. Neural Syst. Rehabil. Eng. 2009, 17, 512-520. [CrossRef] 
57. Merians, A.S.; Fluet, G.G.; Qiu, Q.; Saleh, S.; Lafond, I.; Davidow, A.; Adamovich, S.V. Robotically facilitated virtual rehabilitation of arm transport integrated with finger movement in persons with hemiparesis. $J$. Neuroeng. Rehabil. 2011, 8, 27. [CrossRef]

58. Nagaraj, S.B.; Constantinescu, D. Effect of Haptic Force Feedback on Upper Limb. In Proceedings of the 2009 Second International Conference on Emerging Trends in Engineering \& Technology, Nagpur, India, 16-18 December 2009; pp. 55-58.

59. Chiang, V.C.; Lo, K.H.; Choi, K.S. Rehabilitation of activities of daily living in virtual environments with intuitive user interface and force feedback. Disabil. Rehabil. Assist. Technol. 2017, 12, 672-680. [CrossRef]

60. Sadihov, D.; Migge, B.; Gassert, R.; Kim, Y. Prototype of a VR upper-limb rehabilitation system enhanced with motion-based tactile feedback. In Proceedings of the 2013 World Haptics Conference (WHC), Daejeon, Korea, 14-17 April 2013; pp. 449-454.

61. Kapur, P.; Premakumar, S.; Jax, S.A.; Buxbaum, L.J.; Dawson, A.M.; Kuchenbecker, K.J. Vibrotactile feedback system for intuitive upper-limb rehabilitation. In Proceedings of the World Haptics 2009_Third Joint EuroHaptics Conference and Symposium on Haptic Interfaces for Virtual Environment and Teleoperator Systems, Salt Lake City, UT, USA, 18-20 March 2009; pp. 621-622.

62. Ramírez-Fernández, C.; Morán, A.L.; García-Canseco, E. Haptic feedback in motor hand virtual therapy increases precision and generates less mental workload. In Proceedings of the 2015 9th International Conference on Pervasive Computing Technologies for Healthcare (PervasiveHealth), Istanbul, Turkey, 20-23 May 2015; pp. 280-286.

63. Aminov, A.; Rogers, J.M.; Middleton, S.; Caeyenberghs, K.; Wilson, P.H. What do randomized controlled trials say about virtual rehabilitation in stroke? A systematic literature review and meta-analysis of upper-limb and cognitive outcomes. J. Neuroeng. Rehabil. 2018, 15, 29. [CrossRef] [PubMed]

64. Lohse, K.R.; Hilderman, C.G.; Cheung, K.L.; Tatla, S.; Van der Loos, H.F. Virtual reality therapy for adults post-stroke: A systematic review and meta-analysis exploring virtual environments and commercial games in therapy. PLoS ONE 2014, 9, e93318. [CrossRef] [PubMed]

65. Mekbib, D.B.; Han, J.; Zhang, L.; Fang, S.; Jiang, H.; Zhu, J.; Roe, A.W.; Xu, D. Virtual reality therapy for upper limb rehabilitation in patients with stroke: A meta-analysis of randomized clinical trials. Brain Inj. 2020, 34, 456-465. [CrossRef] [PubMed]

66. Karamians, R.; Proffitt, R.; Kline, D.; Gauthier, L.V. Effectiveness of Virtual Reality- and Gaming-Based Interventions for Upper Extremity Rehabilitation Poststroke: A Meta-analysis. Arch. Phys. Med. Rehabil. 2020, 101, 885-896. [CrossRef]

67. Lee, H.S.; Park, Y.J.; Park, S.W. The Effects of Virtual Reality Training on Function in Chronic Stroke Patients: A Systematic Review and Meta-Analysis. BioMed Res. Int. 2019, 2019, 7595639. [CrossRef]

68. Laver, K.E.; Lange, B.; George, S.; Deutsch, J.E.; Saposnik, G.; Crotty, M. Virtual reality for stroke rehabilitation. Cochrane Database Syst. Rev. 2017, 11, Cd008349. [CrossRef]

69. Shea, B.J.; Reeves, B.C.; Wells, G.; Thuku, M.; Hamel, C.; Moran, J.; Moher, D.; Tugwell, P.; Welch, V.; Kristjansson, E.; et al. AMSTAR 2: A critical appraisal tool for systematic reviews that include randomised or non-randomised studies of healthcare interventions, or both. BMJ 2017, 358, j4008. [CrossRef]

70. Lang, C.E.; Edwards, D.F.; Birkenmeier, R.L.; Dromerick, A.W. Estimating minimal clinically important differences of upper-extremity measures early after stroke. Arch. Phys. Med. Rehabil. 2008, 89, 1693-1700. [CrossRef]

71. Sivan, M.; O’Connor, R.J.; Makower, S.; Levesley, M.; Bhakta, B. Systematic review of outcome measures used in the evaluation of robot-assisted upper limb exercise in stroke. J. Rehabil. Med. 2011, 43, 181-189. [CrossRef]

72. Oman, C.M. Motion sickness: A synthesis and evaluation of the sensory conflict theory. Can. J. Physiol. Pharm. 1990, 68, 294-303. [CrossRef]

73. Qualcomm Developer Network. Reducing Cybersickness in Virtual Reality: What is Cybersickness and how it can be Reduced or Prevented when Developing Virtual Reality Experiences. Available online: https://developer.qualcomm.com/ebook/reducing-cybersickness-virtual-reality (accessed on 20 October 2020).

74. Viau, A.; Feldman, A.G.; McFadyen, B.J.; Levin, M.F. Reaching in reality and virtual reality: A comparison of movement kinematics in healthy subjects and in adults with hemiparesis. J. Neuroeng. Rehabil. 2004, 1, 11. [CrossRef] 
75. Hussain, N.; Alt Murphy, M.; Sunnerhagen, K.S. Upper Limb Kinematics in Stroke and Healthy Controls Using Target-to-Target Task in Virtual Reality. Front. Neurol. 2018, 9, 300. [CrossRef] [PubMed]

76. Magdalon, E.C.; Michaelsen, S.M.; Quevedo, A.A.; Levin, M.F. Comparison of grasping movements made by healthy subjects in a 3-dimensional immersive virtual versus physical environment. Acta Psychol. 2011, 138, 126-134. [CrossRef] [PubMed]

77. Levin, M.F.; Magdalon, E.C.; Michaelsen, S.M.; Quevedo, A.A. Quality of Grasping and the Role of Haptics in a 3-D Immersive Virtual Reality Environment in Individuals With Stroke. IEEE Trans. Neural Syst. Rehabil. Eng. 2015, 23, 1047-1055. [CrossRef] [PubMed]

78. Lott, A.; Bisson, E.; Lajoie, Y.; McComas, J.; Sveistrup, H. The effect of two types of virtual reality on voluntary center of pressure displacement. Cyberpsychology Behav. 2003, 6, 477-485. [CrossRef]

79. Taub, E.; Uswatte, G.; Mark, V.W.; Morris, D.M.; Barman, J.; Bowman, M.H.; Bryson, C.; Delgado, A.; Bishop-McKay, S. Method for enhancing real-world use of a more affected arm in chronic stroke: Transfer package of constraint-induced movement therapy. Stroke 2013, 44, 1383-1388. [CrossRef]

80. Basteris, A.; Nijenhuis, S.M.; Stienen, A.H.; Buurke, J.H.; Prange, G.B.; Amirabdollahian, F. Training modalities in robot-mediated upper limb rehabilitation in stroke: A framework for classification based on a systematic review. J. Neuroeng. Rehabil. 2014, 11, 111. [CrossRef]

81. Levac, D.E.; Huber, M.E.; Sternad, D. Learning and transfer of complex motor skills in virtual reality: A perspective review. J. Neuroeng. Rehabil. 2019, 16, 121. [CrossRef]

82. Rose, F.D.; Attree, E.A.; Brooks, B.M.; Parslow, D.M.; Penn, P.R.; Ambihaipahan, N. Training in virtual environments: Transfer to real world tasks and equivalence to real task training. Ergonomics 2000, 43, 494-511. [CrossRef]

83. De Mello Monteiro, C.B.; Massetti, T.; da Silva, T.D.; van der Kamp, J.; de Abreu, L.C.; Leone, C.; Savelsbergh, G.J. Transfer of motor learning from virtual to natural environments in individuals with cerebral palsy. Res. Dev. Disabil. 2014, 35, 2430-2437. [CrossRef]

84. Massetti, T.; Fávero, F.M.; Menezes, L.D.C.; Alvarez, M.P.B.; Crocetta, T.B.; Guarnieri, R.; Nunes, F.L.S.; Monteiro, C.B.M.; Silva, T.D.D. Achievement of Virtual and Real Objects Using a Short-Term Motor Learning Protocol in People with Duchenne Muscular Dystrophy: A Crossover Randomized Controlled Trial. Games Health J. 2018, 7, 107-115. [CrossRef] [PubMed]

85. Anglin, J.; Saldana, D.; Schmiesing, A.; Liew, S.-L. Transfer of a skilled motor learning task between virtual and conventional environments. In Proceedings of the 2017 IEEE Virtual Reality (VR), Los Angeles, CA, USA, 18-22 March 2017; pp. 401-402.

86. Levac, D.E.; Jovanovic, B.B. Is children's motor learning of a postural reaching task enhanced by practice in a virtual environment? In Proceedings of the 2017 International Conference on Virtual Rehabilitation (ICVR), Montreal, QC, Canada, 19-22 June 2017; pp. 1-7.

87. Sakata, S.; Grove, P.M.; Hill, A.; Watson, M.O.; Stevenson, A.R.L. Impact of simulated three-dimensional perception on precision of depth judgements, technical performance and perceived workload in laparoscopy. Br. J. Surg. 2017, 104, 1097-1106. [CrossRef] [PubMed]

88. Charles, D.; Holmes, D.; Charles, T.; McDonough, S. Virtual Reality Design for Stroke Rehabilitation. Adv. Exp. Med. Biol. 2020, 1235, 53-87. [PubMed]

89. Ebrahimi, E.; Babu, S.V.; Pagano, C.C.; Jörg, S. An empirical evaluation of visuo-haptic feedback on physical reaching behaviors during $3 \mathrm{D}$ interaction in real and immersive virtual environments. ACM Trans. Appl. Percept. TAP 2016, 13, 1-21. [CrossRef]

90. Ranganathan, R.; Wieser, J.; Mosier, K.M.; Mussa-Ivaldi, F.A.; Scheidt, R.A. Learning redundant motor tasks with and without overlapping dimensions: Facilitation and interference effects. J. Neurosci. 2014, 34, 8289-8299. [CrossRef]

91. Deterding, S.; Dixon, D.; Khaled, R.; Nacke, L. From game design elements to gamefulness: Defining "gamification". In Proceedings of the 15th International Academic MindTrek Conference: Envisioning Future Media Environments, Tampere, Finland, 28-30 September 2011; pp. 9-15.

92. Yates, M.; Kelemen, A.; Sik Lanyi, C. Virtual reality gaming in the rehabilitation of the upper extremities post-stroke. Brain Inj. 2016, 30, 855-863. [CrossRef]

93. Mubin, O.; Alnajjar, F.; Al Mahmud, A.; Jishtu, N.; Alsinglawi, B. Exploring serious games for stroke rehabilitation: A scoping review. Disabil. Rehabil. Assist. Technol. 2020, 1-7. [CrossRef] 
94. Shin, J.H.; Ryu, H.; Jang, S.H. A task-specific interactive game-based virtual reality rehabilitation system for patients with stroke: A usability test and two clinical experiments. J. Neuroeng. Rehabil. 2014, 11, 32. [CrossRef]

95. Hocine, N.; Gouaïch, A.; Cerri, S.A.; Mottet, D.; Froger, J.; Laffont, I. Adaptation in serious games for upper-limb rehabilitation: An approach to improve training outcomes. User Modeling User-Adapt. Interact. 2015, 25, 65-98. [CrossRef]

96. Levac, D.; Glegg, S.; Colquhoun, H.; Miller, P.; Noubary, F. Virtual Reality and Active Videogame-Based Practice, Learning Needs, and Preferences: A Cross-Canada Survey of Physical Therapists and Occupational Therapists. Games Health J. 2017, 6, 217-228. [CrossRef]

97. Glegg, S.M.N.; Levac, D.E. Barriers, Facilitators and Interventions to Support Virtual Reality Implementation in Rehabilitation: A Scoping Review. PMER 2018, 10, 1237-1251.e1.

98. Johansson, B.B. Brain plasticity and stroke rehabilitation. The Willis lecture. Stroke 2000, 31, $223-230$. [CrossRef] [PubMed]

99. Pascual-Leone, A.; Amedi, A.; Fregni, F.; Merabet, L.B. The plastic human brain cortex. Annu. Rev. Neurosci. 2005, 28, 377-401. [CrossRef]

100. Nithianantharajah, J.; Hannan, A.J. Enriched environments, experience-dependent plasticity and disorders of the nervous system. Nat. Rev. Neurosci. 2006, 7, 697-709. [CrossRef] [PubMed]

101. Cervera, M.A.; Soekadar, S.R.; Ushiba, J.; Millán, J.D.R.; Liu, M.; Birbaumer, N.; Garipelli, G. Brain-computer interfaces for post-stroke motor rehabilitation: A meta-analysis. Ann. Clin. Transl. Neurol. 2018, 5, 651-663. [CrossRef] [PubMed]

102. Van Dokkum, L.E.H.; Ward, T.; Laffont, I. Brain computer interfaces for neurorehabilitation-Its current status as a rehabilitation strategy post-stroke. Ann. Phys. Rehabil. Med. 2015, 58, 3-8. [CrossRef] [PubMed]

103. Pichiorri, F.; Morone, G.; Petti, M.; Toppi, J.; Pisotta, I.; Molinari, M.; Paolucci, S.; Inghilleri, M.; Astolfi, L.; Cincotti, F.; et al. Brain-computer interface boosts motor imagery practice during stroke recovery. Ann. Neurol. 2015, 77, 851-865. [CrossRef]

104. Vourvopoulos, A.; Pardo, O.M.; Lefebvre, S.; Neureither, M.; Saldana, D.; Jahng, E.; Liew, S.L. Effects of a Brain-Computer Interface With Virtual Reality (VR) Neurofeedback: A Pilot Study in Chronic Stroke Patients. Front. Hum. Neurosci. 2019, 13, 210. [CrossRef]

105. Ward, N.S.; Cohen, L.G. Mechanisms underlying recovery of motor function after stroke. Arch. Neurol. 2004, 61, 1844-1848. [CrossRef]

106. Talelli, P.; Greenwood, R.J.; Rothwell, J.C. Arm function after stroke: Neurophysiological correlates and recovery mechanisms assessed by transcranial magnetic stimulation. Clin. Neurophysiol. 2006, 117, 1641-1659. [CrossRef]

107. Hummel, F.C.; Cohen, L.G. Non-invasive brain stimulation: A new strategy to improve neurorehabilitation after stroke? Lancet Neurol. 2006, 5, 708-712. [CrossRef]

108. Khedr, E.M.; Ahmed, M.A.; Fathy, N.; Rothwell, J.C. Therapeutic trial of repetitive transcranial magnetic stimulation after acute ischemic stroke. Neurology 2005, 65, 466-468. [CrossRef] [PubMed]

109. Gandiga, P.C.; Hummel, F.C.; Cohen, L.G. Transcranial DC stimulation (tDCS): A tool for double-blind sham-controlled clinical studies in brain stimulation. Clin. Neurophysiol. 2006, 117, 845-850. [CrossRef] [PubMed]

110. Hummel, F.; Celnik, P.; Giraux, P.; Floel, A.; Wu, W.H.; Gerloff, C.; Cohen, L.G. Effects of non-invasive cortical stimulation on skilled motor function in chronic stroke. Brain 2005, 128 Pt 3, 490-499. [CrossRef]

111. Mansur, C.G.; Fregni, F.; Boggio, P.S.; Riberto, M.; Gallucci-Neto, J.; Santos, C.M.; Wagner, T.; Rigonatti, S.P.; Marcolin, M.A.; Pascual-Leone, A. A sham stimulation-controlled trial of rTMS of the unaffected hemisphere in stroke patients. Neurology 2005, 64, 1802-1804. [CrossRef]

112. Kim, W.-S.; Kwon, B.S.; Seo, H.G.; Park, J.; Paik, N.-J. Low-frequency repetitive transcranial magnetic stimulation over contralesional motor cortex for motor recovery in subacute ischemic stroke: A randomized sham-controlled trial. Neurorehabil. Neural Repair 2020, 34, 856-867. [CrossRef]

113. Fregni, F.; Boggio, P.S.; Mansur, C.G.; Wagner, T.; Ferreira, M.J.; Lima, M.C.; Rigonatti, S.P.; Marcolin, M.A.; Freedman, S.D.; Nitsche, M.A.; et al. Transcranial direct current stimulation of the unaffected hemisphere in stroke patients. Neuroreport 2005, 16, 1551-1555. [CrossRef] 
114. Vines, B.W.; Cerruti, C.; Schlaug, G. Dual-hemisphere tDCS facilitates greater improvements for healthy subjects' non-dominant hand compared to uni-hemisphere stimulation. BMC Neurosci. 2008, 9, 103. [CrossRef]

115. Floel, A.; Nagorsen, U.; Werhahn, K.J.; Ravindran, S.; Birbaumer, N.; Knecht, S.; Cohen, L.G. Influence of somatosensory input on motor function in patients with chronic stroke. Ann. Neurol. 2004, 56, 206-212. [CrossRef]

116. Sawaki, L.; Wu, C.W.; Kaelin-Lang, A.; Cohen, L.G. Effects of somatosensory stimulation on use-dependent plasticity in chronic stroke. Stroke 2006, 37, 246-247. [CrossRef]

117. Rossi, S.; Hallett, M.; Rossini, P.M.; Pascual-Leone, A. Safety, ethical considerations, and application guidelines for the use of transcranial magnetic stimulation in clinical practice and research. Clin. Neurophysiol. 2009, 120, 2008-2039. [CrossRef] [PubMed]

118. Bikson, M.; Paneri, B.; Mourdoukoutas, A.; Esmaeilpour, Z.; Badran, B.W.; Azzam, R.; Adair, D.; Datta, A.; Fang, X.H.; Wingeier, B.; et al. Limited output transcranial electrical stimulation (LOTES-2017): Engineering principles, regulatory statutes, and industry standards for wellness, over-the-counter, or prescription devices with low risk. Brain Stimul. 2018, 11, 134-157. [CrossRef] [PubMed]

119. Zheng, C.J.; Liao, W.J.; Xia, W.G. Effect of combined low-frequency repetitive transcranial magnetic stimulation and virtual reality training on upper limb function in subacute stroke: A double-blind randomized controlled trail. J. Huazhong Univ. Sci. Technol. Med. Sci. 2015, 35, 248-254. [CrossRef] [PubMed]

120. Johnson, N.N.; Carey, J.; Edelman, B.J.; Doud, A.; Grande, A.; Lakshminarayan, K.; He, B. Combined rTMS and virtual reality brain-computer interface training for motor recovery after stroke. J. Neural Eng. 2018, 15, 016009. [CrossRef] [PubMed]

121. Lee, S.J.; Chun, M.H. Combination transcranial direct current stimulation and virtual reality therapy for upper extremity training in patients with subacute stroke. Arch. Phys. Med. Rehabil. 2014, 95, 431-438. [CrossRef]

122. Sarfo, F.S.; Ulasavets, U.; Opare-Sem, O.K.; Ovbiagele, B. Tele-Rehabilitation after Stroke: An Updated Systematic Review of the Literature. J. Stroke Cereb. Dis 2018, 27, 2306-2318. [CrossRef]

123. Laver, K.E.; Adey-Wakeling, Z.; Crotty, M.; Lannin, N.A.; George, S.; Sherrington, C. Telerehabilitation services for stroke. Cochrane Database Syst. Rev. 2020, 1, Cd010255. [CrossRef]

124. Piron, L.; Turolla, A.; Agostini, M.; Zucconi, C.; Cortese, F.; Zampolini, M.; Zannini, M.; Dam, M.; Ventura, L.; Battauz, M.; et al. Exercises for paretic upper limb after stroke: A combined virtual-reality and telemedicine approach. J. Rehabil. Med. 2009, 41, 1016-1102. [CrossRef]

125. Choi, Y.H.; Ku, J.; Lim, H.; Kim, Y.H.; Paik, N.J. Mobile game-based virtual reality rehabilitation program for upper limb dysfunction after ischemic stroke. Restor. Neurol. Neurosci. 2016, 34, 455-463. [CrossRef]

Publisher's Note: MDPI stays neutral with regard to jurisdictional claims in published maps and institutional affiliations.

(C) 2020 by the authors. Licensee MDPI, Basel, Switzerland. This article is an open access article distributed under the terms and conditions of the Creative Commons Attribution (CC BY) license (http://creativecommons.org/licenses/by/4.0/). 